\title{
A interação retórico-discursiva e suas múltiplas variáveis
}

\author{
The rhetoric discursive interaction and its multiple \\ variables
}

\author{
Melliandro Mendes Galinari \\ Universidade Federal de Ouro Preto - UFOP
}

Fapemig

\section{Resumo}

O presente artigo procura construir uma visão de conjunto acerca dos elementos envolvidos numa interação retórico-discursiva e suas respectivas designações teórico-conceituais. A enunciação, vista sob uma ótica argumentativa e entendida como um processo comunicativo estabelecido entre uma instância de produção e outra de recepção do discurso, institui-se pela atuação de inúmeras variáveis. Como exemplo, pode-se citar os próprios argumentos veiculados pelo discurso (logos, ethos e pathos), as modalidades possíveis de adesão (teses, ações e emoções), o gênero discursivo/textual e uma série de fatores situacionais (orador, auditório, elementos dóxicos, características sócio-históricas, etc.). O artigo, enfim, salienta a importância de se levar em consideração, conjuntamente, tais elementos durante uma análise discursiva e procura aproximar a Análise do Discurso da Retórica e da Sofística.

\section{Palavras-chave}

Análise do Discurso, Argumentação, Retórica, Sofística 


\section{Abstract}

This paper intends to create a combined view on elements involved in a rhetoric discursive interaction and its respective theoretical conceptual designations. The enunciation, analyzed by an argumentative view is understood as a communicative process, established between an instance of production and another of reception of discourse, institutes itself by the interaction of several variables. For example, the own arguments in the discourse can be mentioned (logos, ethos and pathos), possible adhesion modalities (theses, action and emotion), the discursive/textual genre and a series of situational factors (orator, auditorium, social historical characteristics, etc.). This article emphasizes the importance of considering, conjointly, these elements during a discursive analysis and tries to approximate the Discourse Analysis to the Sophistic and the Rhetoric.

\section{Keywords}

Discourse Analysis, Argumentation, Rhetoric, Sophistic 


\section{Introdução}

$\mathrm{H}$ oje sabemos que a argumentação e vários de seus conceitos, como o logos, o ethos e o pathos, tem sido sistematicamente inserida e reaproveitada pelos estudos linguístico-discursivos, seja em suas reflexões teóricas, seja em suas múltiplas análises de corpus. As conexões possíveis entre as categorias e pensamentos retóricos e/ou argumentativos (antigos) e a Linguística discursiva contemporânea não deveriam causar, a meu ver, nenhum espanto, qualquer estranhamento e, menos ainda, sensações eufóricas de novidade. Basta lembrarmos que, no longínquo tempo dos Sofistas, na Atenas do V século a.C., ou seja, na tão falada Era de Péricles, Gramática, Dialética, Retórica e Cultura Geral (VIGNALI, 2007) eram as quatro disciplinas reunidas e solidárias no mesmo engenho de formar eficientemente $\mathrm{o}$ orador, o que nos permite cogitar a existência e persistência, ao longo da longa história, de uma "Arte Geral da Influência”, com foco, no momento em questão, na preparação pragmática do cidadão para os embates da vida pública.

Naquela conjuntura, assim como se delineia hoje, inúmeras questões de língua e estilo ligavam-se já a questões de discurso e a seus impactos no meio social, embora muitas diferenças terminológicas e o ostracismo de que gozam (ainda) os estudos sofísticos no âmbito dos estudos discursivos nos impeçam de ver as ligações. A partir de Aristóteles, tal "Arte Geral da Influência" contaria também, e mais claramente, com uma vertente de cunho teórico-analítico, voltando-se para a especulação filosófica e o estabelecimento daquilo que seria persuasivo em cada caso particular, tendência dada como a mais próxima dos postulados da Análise do Discurso atual (AD). Entretanto, tal vertente mais especulativa ou teórica de Aristóteles, em razão de uma leitura parcial feita por estudiosos atuais do discurso, contrapõe-se ao suposto utilitarismo pragmático dos sofistas apenas em aparência: em diversos momentos da Retórica aristotélica vê-se claramente que o autor dá "conselhos" para o êxito prático do orador na vida pública. Em contrapartida, os sofistas, como se verá rapidamente na 
conclusão deste artigo, procuraram a seu modo tecer considerações de cunho teórico, das quais a $\mathrm{AD}$ atual poderia igualmente tirar proveito.

Com a decadência da Retórica em seu aspecto combativo/controverso, fenômeno bastante teorizado aqui e ali, com o seu resgate no século XX pelas mãos de Perelman e Olbrechts-Tyteca (2002), Toulmin (1958) e outros, e com o desenvolvimento da Linguística do discurso, é verossímil dizer que, atualmente, os "cacos" daquela ciência geral da influência, que havia se quebrado, ${ }^{1}$ vêm se recompondo no interior do campo disciplinar da $\mathrm{AD}$, o que nos leva fatalmente a indagar: não seria a $\mathrm{AD}$ uma neorretórica a seu modo, com seus encaminhamentos teóricos particulares/modernos? E, da mesma forma, não seria a antiga Retórica em seu conjunto (ou seja, não somente Aristóteles, mas também as reflexões dos Sofistas, de Cícero, de Quintiliano e outros) uma AD avant la lettre? Noutras palavras, é difícil afirmar se o que está ocorrendo hoje é realmente uma "apropriação" por parte de um campo disciplinar (os estudos linguístico-discursivos) de conceitos de outro campo mais antigo, o da Retórica, ou se, na verdade, aquilo a que estamos assistindo é uma recomposição ou reunificação de uma Arte Geral da Influência no espaço interdisciplinar e contemporâneo da AD.

Querelas à parte, procuro neste texto traçar um panorama geral das variáveis mínimas que integram uma interação retórico-discursiva, apoiando-me nas reflexões retóricas antigas e modernas e nos postulados da Análise do Discurso, mas sem me preocupar com uma distinção rígida entre Análise do Discurso, Retórica ou Sofística. Essa visão geral do que acontece numa interação e do que o analista do discurso vai à caça para realizar o seu trabalho visa alertar para uma "malícia teórica" que deveríamos ter antes de partirmos para uma análise de corpus, pois existem muitas variáveis a serem consideradas, conjuntamente, ao redor de um objeto discursivo. 


\section{2. $O$ processo enunciativo/argumentativo}

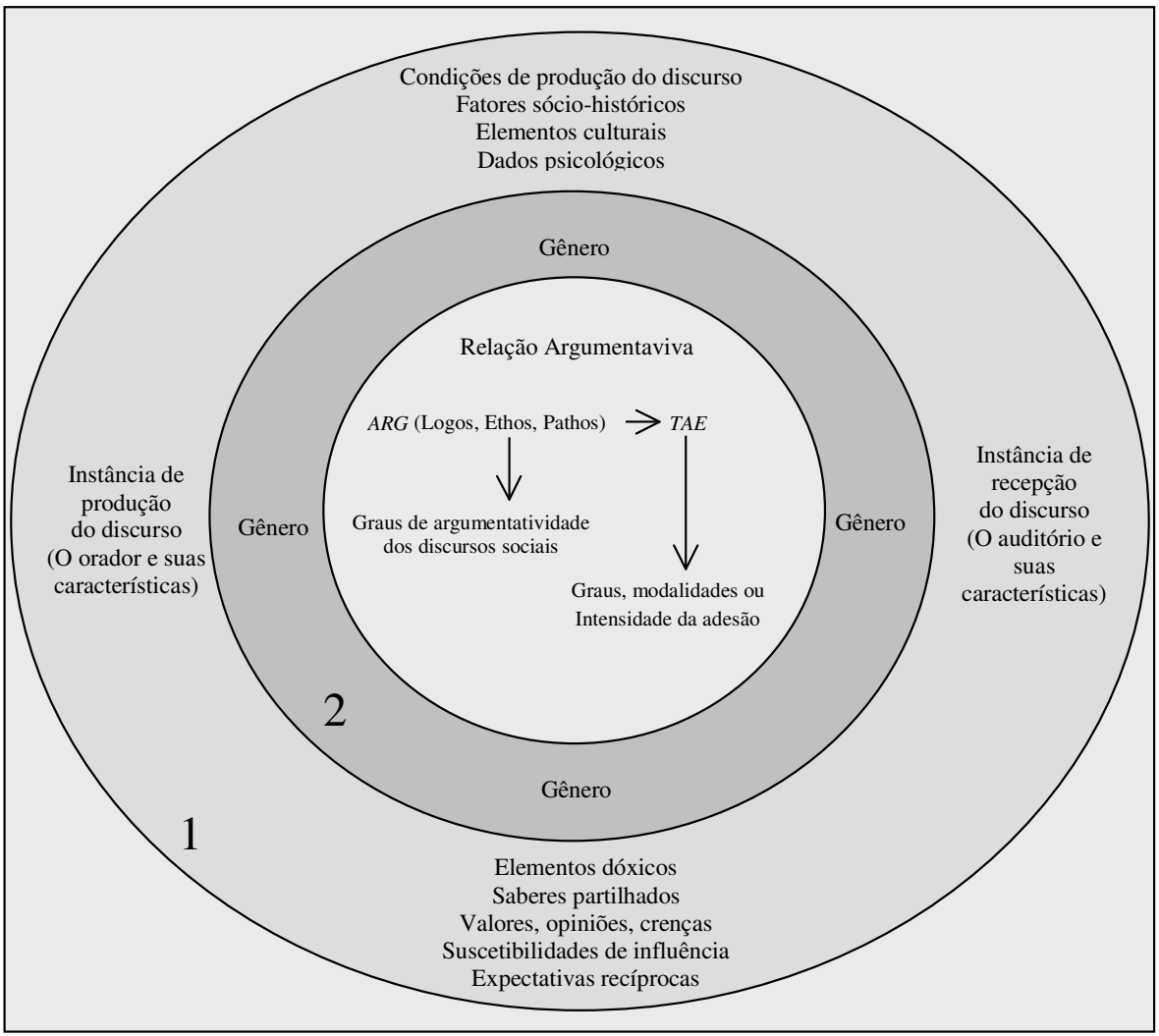

Figura 1

Apresento, então, um possível Esquema Geral do Processo Enunciativo/Argumentativo, que comportaria as várias variáveis envolvidas numa interação retórico-discursiva, agrupadas acima em três níveis: (i) a moldura sócio-histórica e situacional na qual a argumentação se desenvolve, com as suas respectivas variáveis ou categorias teóricas [faixa 1], (ii) um gênero que funciona como "ambiente textual/discursivo" e veículo para a interação argumentativa [faixa 2] e, finalmente, (iii) uma relação argumentativa visível com base nos textos fixados como corpora pelo analista do discurso [centro da figura]. Não poderei tratar em profundidade de cada detalhe da figura acima, mas procurarei traçar aqui uma visão de conjunto dos elementos importantes que 
deveríamos levar em consideração durante uma atividade de análise discursiva ou argumentativa. Comecemos, portanto, pela parte central e interna do esquema: pelo seu "olho".

\subsection{A relação argumentativa}

Inicialmente, seria interessante reafirmar a posição já expressa em Galinari (2007a e 2007b) de que precisamos ter em mente uma concepção mais ampla da argumentação e de seus efeitos (possíveis) num eventual auditório, antes de partirmos para a análise de corpus propriamente dita. A argumentação não se reduz à abordagem, muito difundida, de que um discurso retórico desencadeia um processo de adesão estritamente cognitivo, "mental", no sentido de influenciar seus interlocutores em termos de "teses" sobre o mundo.

Os próprios autores citados correntemente como fontes legitimantes dessa perspectiva (PERELMAN; OLBRECHTS-TYTECA, 2002), pelo fato de terem dito que a argumentação seria $o$ ato de "provocar ou aumentar a adesão dos espíritos às teses que se apresentam a seu assentimento" (PERELMAN; OLBRECHTS-TYTECA, 2002, p. 50) (grifo meu), logo em seguida revelam que tal posicionamento teórico é limitado, ou melhor, que ele representa "uma concepção errônea dos efeitos da argumentação":

(...) a eficácia de uma exposição, tendente a obter dos ouvintes uma adesão suficiente às teses apresentadas, só pode ser julgada pelo objetivo que o orador se propõe. A intensidade da adesão que se tem de obter não se limita à produção de resultados puramente intelectuais, ao fato de declarar que uma tese parece mais provável que outra, mas muitas vezes será reforçada até que a ação, que ela deveria desencadear, tenha ocorrido. (PERELMAN; OLBRECHTSTYTECA, 2002, p. 54) (grifo nosso)

Temos aí uma variável chamada intensidade da adesão que não se restringe à transmissão persuasiva de ideias abstratas (um "fazer-crer" em teses): discursos políticos, publicitários e tantos outros possuem como meta retórica principal a instituição de ações ou comportamentos, tais como "fazervotar" ou "fazer-comprar/consumir". Obviamente, isso não exclui uma dimensão racional da adesão, que muitas vezes funciona como um "meio intermediário" para se chegar a outros fins: "fazer-crer" para "fazer-fazer" ou "fazer-crer" 
para "fazer-sentir", etc. A propósito, com o resgate recente das emoções no plano teórico, ${ }^{2}$ podemos ainda acrescentar que afetos e sentimentos são elementos integrantes de uma determinada intensidade da adesão: pode-se querer, simplesmente, "fazer-sentir", ou "fazer-sentir" para "fazer-fazer", ou, ainda, "fazer-sentir" para "fazer-crer". Acredito, em razão desse leque amplo de possibilidades, que uma consideração conjunta dos três elementos básicos da intensidade de adesão - teses, ações e emoções -, a meu ver indissociáveis, poderia abrir caminho para um melhor entendimento das reais potencialidades de influência dos discursos sociais. Se partirmos para as nossas análises com essa "malícia teórica" prévia será muito produtivo. Seria, pois, uma forma de perguntarmos aos nossos corpora: o que queres (ou podes) tu ocasionar em função de teu contexto de circulação, das características psicológicas e sociais dos sujeitos sociais que colocas em interação? Queres tu apenas fazer-crer em algo? Levar alguém a agir ou a se comportar de tal modo? A sentir algo? Um pouco de tudo isso?

Voltando, então, ao "olho" do esquema apresentado [figura 1], encontra-se sistematizada o que eu prefiro chamar agora de relação argumentativa, e não mais processo enunciativo/argumentativo, como fiz na bibliografia mencionada (GALINARI, 2007a e 2007b), visto que tal processo é, na verdade, o todo da figura, ou seja, a completude das variáveis contidas numa interação retórica nos seus três níveis citados, objeto geral deste texto. A relação argumentativa ARG (LOGOS, ETHOS E PATHOS) $\rightarrow$ TAE pode ser descrita da seguinte maneira, como já tenho feito: à direita da seta, temos as variáveis da intensidade de adesão (teses, ações e emoções) visadas por um discurso persuasivo e, à esquerda, os seus elementos deflagradores (os argumentos ou provas retóricas). Note-se que, por um lado, temos a dimensão ou intenção retórica dos discursos sociais, isto é, um certo grau de argumentatividade (retomando uma expressão de Amossy [2006]), que vai se configurar em função de um contexto situacional e de um enquadramento genérico. Por outro lado, coerentemente, temos um grau (possível) de adesão. Essa seria, teoricamente, a relação argumentativa básica que apreenderíamos, enquanto analistas do discurso, com base em qualquer texto que julgamos capaz de influenciar, tendo em mente a interrelação das provas retóricas e as formas possíveis da adesão. ${ }^{3}$

Com o esquema da relação argumentativa [ARG (LOGOS, ETHOS E PATHOS) $\rightarrow$ TAE], tenho procurado nem tanto apresentar novidades, mas 
ampliar (e reaproveitar), em benefício de nossas análises, "fórmulas" presentes em Toulmin (1958), Anscombre \& Ducrot (1983), Charaudeau (1992) e Plantin (1996), pois acredito que estas, da maneira como foram apresentadas, consideram como efeito possível da argumentação uma adesão traduzível em teses sobre o mundo, dando atenção menor (ou nula) às ações ou comportamentos e às emoções. Assim, somos comumente confrontados a estruturações do tipo: (i) $\mathbf{A} \rightarrow \mathbf{C}$ (ou $\mathbf{A} \rightarrow \mathbf{T}$ ), que esquematizam a passagem de um argumento a uma conclusão ou tese, e (ii) $\mathbf{E} 1 \rightarrow \mathbf{E} 2$, que esquematiza a passagem de um enunciado 1, com valor de argumento, a um enunciado 2, com valor conclusivo. Essa redução teórica da adesão a resultados meramente intelectuais parece ter origem na concepção estritamente racional do logos, proveniente de uma releitura provavelmente equivocada de Aristóteles, onde logos é sinônimo de demonstração (verdadeira ou aparente), sendo tais demonstrações portadoras de conclusões ou teses, seja pelo método da dedução entimemática, que encontra a sua forma plena no silogismo dialético, seja pelo artifício do exemplo, que se constrói com a técnica da indução.

Sabemos, contudo, que Aristóteles leva em consideração também o pathos e as paixões dirigidas ao auditório e, ao teorizar sobre a oratória judicial e deliberativa, deixa a entender que o discurso retórico pode se dirigir a ações, ao fazer-deliberar, ao fazer-julgar. E o que dizer dos Sofistas, como Protágoras de Abdera ou Górgias de Leontini, que se colocaram a serviço da formação de uma areté (virtude) política, exigência mor da democracia ateniense, onde a palavra (logos) não se restringia apenas aos âmbitos teóricos, privados ou dialéticos, mas às ações políticas e públicas? Lembremos que, no tempo dos Sofistas e de Péricles, os cargos públicos e as magistraturas não eram mais distribuídos pelo direito oligárquico de sangue, mas através do preparo e do mérito individual daqueles que se sobressaíam pela performance oratória, e aí entrava a importância educativa dos Sofistas na formação de um cidadão ativo (VIGNALI, 2007). Enfim, as ações e as emoções não escapavam à consciência teórica e especulativa daqueles pensadores, que tinham a perfeita noção de que, valendo-me das palavras de Górgias,

o discurso [logos] é um tirano poderoso que, com um corpo microscópico e invisível, executa acções divinas. Consegue suprimir o medo e pôr termo à dor e despertar a alegria e intensificar a paixão. (...) Os encantamentos inspirados pelas palavras levam ao prazer 
e libertam da dor. Na verdade, a força do encantamento, misturandose com a opinião da alma, sedu-la, persuade-a e transforma-a por feitiçaria. (...) A força do discurso em relação à disposição da alma é comparável às prescrições dos medicamentos em relação à natureza dos corpos. Assim como os diferentes medicamentos expulsam do corpo os diferentes humores e uns põem termo à doença e outros à vida, assim também de entre os discursos uns entristecem e outros alegram, uns amedrontam e outros incutem coragem nos ouvintes, outros há que envenenam e enfeitiçam a alma com uma persuasão perniciosa (GÓRGIAS, Elogio de Helena, in PINTO e SOUZA, 2005, p. 127-133).

O logos gorgiano, então, para (re)agir, depende do interlocutor, misturase com as suas opiniões atingindo a sua subjetividade, seus valores e imaginários; além de tudo, é comparável à magia, à feitiçaria e ao poder dos fármacos, tendo consequências múltiplas no plano da adesão. Parece-me que temos aqui uma visão mais ampla do logos grego, ou pelo menos uma visão a mais, que não se reduz a uma perspectiva estritamente racional e de instituição intelectual de teses sobre o mundo. Em relação ao "olho" da figura, resta-me dizer que teríamos muito ainda o que fazer para aperfeiçoar uma metodologia de análise argumentativa e estabelecer, assim, os mecanismos de configuração linguística dos argumentos ou provas retóricas (logos, ethos e pathos), ressaltando, ao mesmo tempo, os efeitos possíveis desses elementos, ou seja, a sua capacidade de instaurar crenças, opiniões, teses, sentimentos, comportamentos ou ações.

\subsection{A importância dos gêneros para a análise argumentativa}

Além da relação argumentativa, é interessante para a análise levar em consideração - e aí passamos à camada imediatamente exterior ao "olho" da figura 1 - o gênero do discurso em estudo, se se trata, por exemplo, de um outdoor publicitário, de uma alocução de comício político ou de uma canção popular, e assim por diante. Isso porque a relação argumentativa, já exposta, é concretizada no interior de um "ambiente" discursivo/textual, veículo indispensável da atividade retórica. Sendo assim, o pertencimento do discurso a um gênero já funcionaria para nós como um indício de quais tipos preponderantes de argumentos poderíamos encontrar na estrutura textual e quais modalidades da 
adesão eles poderiam instituir, levando-se em consideração, é claro, que o enquadramento genérico é incontornavelmente construído pelas condições de produção do discurso e suas respectivas variáveis. Um gênero artigo acadêmico como este, por exemplo, poderia apenas fazer-crer em teses teóricas, embora essa fosse apenas a face mais aparente da adesão, pois o conteúdo poderia influenciar, num segundo momento, a práxis de análise de algum leitor (fazeranalisar). Trata-se, em suma, de dinâmicas próprias ao campo institucional acadêmico; já um gênero jingle político poderia sobretudo fazer-fazer, isto é, fazer-dar-o-voto ao candidato " $x$ ", e não ao candidato " $y$ ", o que não exclui como meios intermeditários uma adesão racional (fazer-crer) própria do campo político ideológico ou, mesmo, uma adesão sentimental (fazer-sentir). Pode-se dizer, assim, que os efeitos persuasivos variam segundo o gênero utilizado, que também influi na configuração dos argumentos, ou melhor, na predominância do ethos, do pathos ou do logos e nos seus modos de inter-relação.

Como bem ressalta Amossy (2006, p. 215-217), os gêneros, com a sua carga retórica específica, são capazes de socializar a palavra individual, encaixando-a em formas conhecidas e repertoriáveis, que determinam um certo horizonte de expectativas; são importantes como elementos mediadores da comunicação, instauram a finalidade da troca, a distribuição dos papéis e as relações de força entre os parceiros. A propósito, a colocação dos papéis pelos gêneros discursivos liga-se à construção do ethos e também à presença em maior ou menor grau do pathos. No gênero alocução de comício político-eleitoral, por exemplo, o homem público (candidato) poderia assumir um papel messiânico, até mesmo numa relação de intertextualidade com a bíblia, ou de ex-sindicalista etc., contando com um auditório capaz de avaliar tais ethé como "compatíveis" ao exercício do poder público. O gênero assim o permite. Pelo contrário, não caberia a ele um papel ou comportamento discursivo de locutor de futebol, próprio do gênero narração de jogo (ao vivo), em que o narrador, apesar de desenvolver seu ethos particular e característico, influi nitidamente nas emoções de quem assiste à partida. No caso dos argumentos mais racionais ou demostrativos, ligados ao logos aristotélico, eles seriam também mais ou menos desenvolvidos de acordo com o gênero, como é o caso dos textos acadêmicos (artigos, teses, dissertações...), embora de uma maneira ou outra acabe-se construindo um ethos do orador-pesquisador, que não deixa de ter/mostrar o seu estilo e posicionamento. 
A importância de se abordar, em determinado momento da análise, o enquadramento genérico do discurso, o seu histórico de funcionamento social, a sua recorrência, as suas funções e configurações possíveis, parece gozar de um certo consenso entre linguistas do discurso, visto que, para o estudioso, tais variáveis acabam revelando de antemão algo significativo sobre o seu objeto. ${ }^{4}$ O problema da categoria "gênero" continua sendo a dificuldade de defini-la precisamente e de torná-la operativa para a análise linguístico-discursiva que virá pela frente. Infelizmente, não há espaço aqui para realizar essa façanha, mas, sim, ressaltar que a consideração da dimensão genérica do discurso pode ser frutífera para a análise discursiva/argumentativa. Passemos, então, à camada exterior do Esquema do Processo Argumentativo/Enunciativo e as suas respectivas categorias teóricas.

\subsection{Condições de produção e conceitos afins}

As condições de produção do discurso, também sistematizadas na imagem do processo enunciativo/argumentativo (figura 1), representam a moldura sócio-histórica e cultural dos enunciados fixados como corpora pelo analista e, por isso, comportam uma série de váriaveis e informações fundamentais para a interpretação dos efeitos de sentido e da funcionalidade dos discursos sociais. Eis alguns exemplos de tais variáveis: as figuras centrais do orador e do auditório, as suas intenções, as suas características e estatutos sociais, as suas competências discursivas, as suas suscetibilidades de influência, a época ou o arco de tempo no qual circulou o corpus, as características históricas, culturais e psicossociais de tal conjuntura, as crenças e valores partilhados, as representações dominantes ou conhecidas, etc. Trata-se, enfim, da "realidade efetiva" do discurso, ou seja, de tudo aquilo que está ao seu redor (espacialmente/temporalmente/ simbolicamente), constituindo-o e sendo constituído/modificado por ele, em função de uma ou várias circunstâncias enunciativas particulares.

Numa perspectiva teórica ou noutra, analistas do discurso têm trabalhado para tornar operativas as informações conjunturais/situacionais em benefício das análises discursivas, elaborando reflexões e processos metodológicos, o que aponta para a existência de um consenso, mesmo que relativo, entre as variadas correntes ou teorias em AD. No caso da argumentação, não poderia ser diferente: como bem relata Amossy (2006, p. 3), 
(...) l'analyse argumentative se présente comme une branche de l'analyse du discours $(\mathrm{AD})$ dans la mesure où elle entend éclaircir des fonctionnements discursifs en explorant une parole située et au moins partiellement contrainte. Telle que la définissent les tendances françaises contemporaines (...), il s'agit d'une discipline (1) rapportant la parole à un lieu social et à des cadres institutionnels, (2) dépassant l'opposition texte/contexte: le statut de l'orateur, les circonstances socio-historique dans lesquelles il prend la parole ou la plume, la nature de l'auditoire visé, la distribution préalable des rôles que l'interaction accepte ou tente de déjouer, les opinions et les croyances qui circulent à l'époque, sont autant de facteurs qui construisent le discours et dont l'analyse interne doit tenir compte, (3) refusant de poser à la source du discours « un sujet énonciateur individuel qui serait maître chez lui » (Mazière, 2005:5) : le locuteur est toujours, comme l'auditoire, traversé par la parole de l'autre, par les idées reçues et les évidences d'une époque, et de ce fait conditionné par les possibles de son temps. ${ }^{5}$

Nos anos de consolidação da Análise do Discurso na França, ou seja, nas décadas de 1960e 1970, Michel Pêcheux procurou elaborar as primeiras considerações sobre as condições de produção do discurso e sobre a sua importância teórica para a realização das análises propriamente ditas, apropriando-se de conceitos oriundos de outras áreas do conhecimento (História, Filosofia, Ciências Sociais...) e dialogando com pensadores como Louis Althusser e Michel Foucault. Para Pêcheux (1997, p. 77), todo discurso surge apoiado em determinadas condições de produção, como aquelas que caracterizam o campo político ou o religioso, e é sempre produzido por sujeitos sociais que participam de relações de força movidas por posicionamentos antagônicos. Segundo ele, as condições de produção implicam a relação de duas instâncias de discurso (A $\rightarrow$ "destinador" e B $\rightarrow$ “destinatário"), não se tratando tanto, aqui, da presença física de dois organismos individuais:

(...) A e B designam lugares determinados na estrutura de uma formação social, lugares dos quais a sociologia pode descrever o feixe de traços objetivos característicos: assim, por exemplo, no interior da esfera da produção econômica, os lugares do "patrão" (diretor, chefe da empresa etc.), do funcionário de repartição, do contramestre, do operário, são marcados por propriedades diferenciais determináveis (PÊCHEUX, 1997, p. 82). 
Esse era, nos idos tempos da década de 1960, um ponto de vista dado, hoje, como "mais rígido", embora não menos interessante, na medida em que dá margem à interpretação de que o sujeito, com a sua subjetividade ou a sua individualidade ("meras ilusões"), não marca tanto uma presença em seu próprio enunciado, sendo este uma (re)produção do lugar institucional de onde o indivíduo fala. Por isso temos, por exemplo, o lugar do patrão, como disse acima Pêcheux, ou o lugar institucional da Presidência da República, e assim por diante, que determinariam (ou melhor, "assujeitariam") as falas dos sujeitos que por ventura viessem a ocupar tais lugares. Essa rigidez, entretanto, não seria tanto um engano teórico ou, mesmo, uma imaturidade/ingenuidade de uma disciplina nascente a AD -, mas, certamente, uma necessidade de mostrar enfaticamente, diante do império estruturalista, que a linguagem está visceralmente ligada aos espaços sociais/institucionais, à luta pelo poder e à política como arte e elemento opressor, assim como às suas formações discursivas e ideologias dominantes, e que havia a necessidade de entendê-la - a linguagem - nessa dinâmica, onde o homem é um ser social e determinado/formado discursivamente pelo seu meio. No que o Estruturalismo pecava, a AD nascente transbordava...

Superada essa questão, o conceito de condições de produção ganhou uma certa maleabilidade a partir de teóricos como Charaudeau, Maingueneau e outros, admitindo-se que existe, por menor que seja, um espaço para o sujeito em sua própria manifestação discursiva, para o seu estilo e individualidade, o que vai depender também da situação e do seu grau (maior ou menor) de formalidade e/ou predeterminação dos papéis discursivos. A linguagem e o homem, aqui, não deixam de ser concebidos como um produto do meio, nem como elementos de construção do meio, mas reconhece-se, também, a subjetividade dos indivíduos nas suas produções verbais. Em relação a isso, Machado (2001, p. 46), falando da Teoria Semiolinguística, de Patrick Charaudeau, nos dá uma boa síntese de como a questão é vista hoje:

o Homem é um ser social (sentido amplo da palavra), criado/ condicionado pela sociedade/cultura do lugar onde vive. Logo, enquanto sujeito-falante, ele "repete" a voz do social, mas o lado psicossocial-situacional lhe garante também uma individualidade. Nem completamente individual, nem completamente coletivo: um amálgama dos dois. 
Em relação à Teoria Semiolinguística, uma tentativa interessante de operacionalização dos elementos situacionais em benefício das análises discursivas/argumentativas está na formalização do conceito-metáfora de "contrato de comunicação". Tal conceito abarcaria boa parte das informações contextuais mais importantes para se enfatizar no início de uma análise, no sentido de elucidar os efeitos possíveis que uma manifestação linguístico-discursiva teria sobre o(s) interlocutor(es). Com o referido conceito, enfatiza-se a existência de acordos estabelecidos pelos parceiros da troca e de convenções sociodiscursivas. Um contrato de comunicação, assim como um contrato jurídico, seria, pode-se interpretar, constituído de "cláusulas" básicas a serem descritas pelo analista: (i) a identidade psicossocial dos parceiros, ou seja, daqueles que falam ou escrevem (quem comunica com quem? Quais papéis/estatutos linguageiros eles possuem?); (ii) a finalidade do ato de linguagem (o sujeito falante está aqui para fazer o quê e para dizer o quê?); (iii) o conteúdo temático mais ou menos estabelecido e/ou previsto pela situação (qual é o assunto da conversação? Os parceiros comunicam para falar de quê? De quais temas?); (iv) os recursos, canais ou circunstâncias materiais da comunicação (os sujeitos comunicam em qual ambiente, com quais recursos, valendo-se de qual canal de transmissão?) (CHARAUDEAU, 1983 e 1994).

Roulet, Filliettaz \& Grobet (2001), Roulet \& Pires (2001), Marinho, Pires \& Villela (2007), no âmbito da Teoria Modular, também procuram, de um modo particular, operacionalizar as informações contextuais em proveito das análises discursivas. Nesse sentido, dois "módulos" em particular da mencionada teoria chamam atenção: o Módulo Referencial e o Módulo Interacional. O primeiro engloba instrumentos metodológicos que permitem descrever o entorno histórico do discurso analisado, assim como as representações conceituais e a estrutura acional aí presentes:

o módulo referencial define não só as representações como também as estruturas praxeológicas das ações, seres e objetos que constituem os universos do discurso, ou seja, tanto o universo no qual se inscreve o discurso como aquele que se revela através do discurso (ROULET; PIRES, 2001, p. 73).

O Módulo Interacional, por sua vez, procura descrever pormenorizadamente a materialidade das interações subjacentes a um dado discurso, enfatizando três 
parâmetros essenciais de qualquer comunicação: (i) o canal da interação, ou seja, o suporte físico utilizado pelos interactantes: se se trata de um canal oral, escrito ou visual, por exemplo; (ii) o modo da interação, ou melhor, o grau de copresença espacial e temporal dos interactantes; (iii) o elo da interação, ou seja, a retroação, que revela se há reciprocidade ou não reciprocidade entre os interactantes. A teoria conta com um interessante quadro, que não apresentarei aqui, ${ }^{6}$ capaz de caracterizar qualquer interação através de tais parâmetros, essenciais para a análise de um discurso e para a elucidação de seus efeitos, na visão dos pesquisadores envolvidos nessa perspectiva teórica (modular).

Enfim, independentemente da teoria ou das teorias adotadas, seria em função da consideração de parâmetros situacionais como os expostos acima, somados às características do período histórico (ou arco de tempo) no qual circulou o corpus, que poderíamos elucidar a maneira pela qual as formas da língua são/estão organizadas de modo a atender determinadas demandas sociais. No caso da argumentação, saberíamos melhor (ou teríamos uma "pista" a priori) sobre as modalidades de influência possíveis e/ou visadas pelo discurso, ou seja, a sua prioridade em relação à instituição de teses, ações ou emoções, sejam elas quais forem. Da mesma forma, construiríamos melhor alguma expectativa em relação aos elementos deflagradores destas três variáveis, ou seja, os argumentos e sua tríplice natureza: logos, ethos e pathos.

Entretanto, a noção de condições de produção do discurso não é uma noção tão simples quanto possa parecer. Maingueneau (1991) a problematiza pela dificuldade de defini-la claramente, apesar ser muito utilizada pela AD com a designação geral de um "contexto social" que "envolve" um corpus, ou de elementos que permitam descrever uma "conjuntura". Apoiando-se em Bakhtin, o autor diz o seguinte:

s'il est vrai que, comme l'écrivait Bakhtine, «en aucun cas la situation extraverbale n'est uniquement la cause extérieure de l'énoncé, [qu'] elle n'agit pas du dehors comme une force mécanique», mais entre dans l'énoncé comme «un constituant nécessaire de sa structure sémantique», alors il faut reconnaître que dans son usage courant la notion de «conditions de production» se révèle tout à fait insuffisante $^{7}$ (MAINGUENEAU, 1991, p. 188). 
Essa insuficiência é preenchida em seu trabalho com o acréscimo de conceitos salutares para a $\mathrm{AD}$, entre os quais ficarei aqui com a noção de interdiscurso, que nos permite contestar "la trompeuse évidence de la conception qui oppose à un 'intérieur' du texte l' 'extérieur' des conditions qui les rendent possibles" (MAINGUENEAU, 1991, p. 188). Ameu ver, o "primado da interdiscursividade" viria assegurar à dita realidade externa, ou seja, às circunstâncias materiais de produção do discurso, um caráter também discursivo e simbólico, pois, como diria Maingueneau (1991, p. 20), o dizer é inseparável de um interdizer. Ao falar de condições de produção, não imagino, portanto, uma "realidade extralinguística" (ou "pré-discursiva") demarcada do discurso a ser analisado, instituindo-o mecanicamente. 9 . Acredito que tal "realidade", supostamente externa, onde se encontram os seres empíricos e as variáveis psicossocioculturais, também é plenamente constituída de linguagem e, no fundo, é ela em si também linguagem para nós, pois o discurso analisado pelo pesquisador, ou melhor, fixado por ele como corpus e ponto de referência, coexiste, relaciona-se e/ou constituise de outros discursos que se imbricam no presente ou momento histórico da enunciação, o que comumente se chama de interdiscurso.

Sendo assim, para o analista, cada corpus instituiria uma busca por essa "parafernália simbólica" que o constituiu como discurso e que, reciprocamente, também acabou sendo constituída por ele quando de sua enunciação. Por outro lado, o homem (ou analista) só poderia acessar esse "mundo real", pretensamente extralinguístico, através do material simbólico que o reveste e, concomitantemente, com o material semiótico que constitui a sua própria subjetividade, isto é, suas vivências e competências linguístico-discursivas, o que o leva a produzir uma leitura que nunca pode ser confundida com uma descrição objetiva do contexto ("imparcial" ou rigorosamente científica). Isso fica mais evidente quando devemos "descrever" um contexto histórico ou as condições de produção de um discurso enunciado há 50 ou 100 anos. Só temos acesso àquela realidade através de discursos: sejam eles arquivos ou documentos disponíveis em acervos ou museus, sejam eles bibliografias historiográficas concernentes ao período, onde pode não haver consenso sobre as "reais" características da conjuntura em questão.

Aqui está, pois, a importância da noção de interdiscurso sempre que falamos de condições de produção: ela permite ver claramente que tais condições são (re)constituídas com o auxílio de outros discursos, ou melhor, que são acessíveis ao analista através de discursos, e que, portanto, não se trata de uma 
realidade mecânica e objetiva-"extraverbal", "extralinguística" ou "extrassemiótica" - determinadora dos corpora analisados e à espera de um pesquisador capaz de reproduzi-la fielmente. ${ }^{10}$ Com a noção de interdiscurso pode-se, enfim, problematizar a tão falada descrição do contexto realizada por nós como praxe epistemológica e termos, mais que tudo, uma maior consciência do nosso fazer acadêmico/discursivo: essa descrição do contexto é infalível? Reproduz a realidade tal como ela é? Ou acaba sendo uma leitura particular do analista, em função das fontes (inter)discursivas que ele consulta sobre/no contexto? Precisamos pensar mais nessas questões se admitimos que a Linguística discursiva/argumentativa é antes de tudo uma Ciência Humana, falível e sujeita a controvérsias.

Por fim, caberia ainda ressaltar que, no interdiscurso, ligadas às condições de produção, encontram-se várias outras variáveis já tratadas pelos antigos e que se mostram de suma importância para a determinação dos sentidos e efeitos dos enunciados sociais, a saber, os valores, as representações, os saberes e os conhecimentos partilhados, presentes nas reflexões antigas sob o nome de topos, por um lado, e doxa, por outro. Seriam esses mecanismos que viabilizariam a passagem de ARG a TAE, ou seja, que autorizariam propriamente um argumento a desencadear intensidades de adesão determinadas. Em outros termos, a "travessia" simbolizada pela seta da relação argumentativa $\rightarrow$ realizase via articulação de elementos dóxicos ou, noutras palavras, via atuação de saberes partilhados. Trata-se de uma complexa e fluida "trama" de ideias comuns: conhecimentos prévios, representações sociais, juízos de valor, estereótipos, provérbios, clichês etc. ${ }^{11}$ Nessa lista, incluir-se-ia tudo aquilo que se encontra no "território comum" entre locutor e alocutário.

Em teoria, isso implica também especular (na medida do possível, é claro) sobre os auditórios possíveis de um dado discurso e, mais ainda, sobre as suas suscetibilidades de influência, a sua adesão a certos valores e representações, os seus conhecimentos e visões de mundo, as suas características psicológicas e outras informações dessa natureza, pois tudo isso, fazendo parte da subjetividade do auditório, permitirá a ele no momento da interação avaliar os argumentos apresentados (logos, ethos e pathos), o que resultará (ou não) em determinados tipos de adesão. Por exemplo: um político-candidato, querendo através de seu discurso instituir a ação de fazer-votar, poderia construir estrategicamente um ethos ou imagem de si de "economista" ou de sujeito 
"entendido" do assunto, valendo-se do léxico complexo e dos jargões próprios a esse campo da atividade humana. Essa adesão só ocorrerá ou se tornará provável se o auditório for propenso a avaliar tal ethos como algo positivo e apropriado para o exercício do poder, ou se o auditório pelo menos possuir uma inclinação para tal avaliação ou, ainda, tiver pouca previsibilidade de rejeição a tal ethos. Ora, para que isso seja possível, esse auditório (ou parcela dele) deve partilhar certas representações positivas sobre o campo da economia, possuir determinados valores e conhecer estereótipos políticos ligados ao ethos veiculado.

Daí, enfim, a importância para a análise e para a elucidação dos efeitos possíveis do discurso de se considerar o auditório e a sua posição diante da doxa, pois este, para sofrer essa ou aquela modalidade da adesão, realiza conscientemente ou não um julgamento responsivo-moral dos "objetos discursivos" a ele apresentados (algo, alguém, uma ideia, um fato, um argumento, um raciocínio, uma imagem de si...), ${ }^{12}$ via visões de mundo, valores e representações presentes em sua subjetividade. Termino, então, minhas considerações panorâmicas em relação ao Esquema do Processo Enunciativo/Argumentativo [figura 1], onde, acredito, as condições de produção representam uma rede conceitual importante, principalmente quando associada à noção teórica de interdiscurso e aos diversos elementos dóxicos aí presentes. Considerando-se o Esquema como um todo, pode-se dizer que cada discurso representado por um corpus institui, em seu(s) presente(s) enunciativo(s), um processo argumentativo particular, onde cada categoria teórica aqui apresentada ganha nuances e significações específicas; procurei sistematizar esse processo enunciativo/argumentativo num esquema circular, fruto de uma tentativa de compreensão do todo da interação retórica e, portanto, longe de ser algo definitivo ou absoluto, podendo sempre sofrer alterações, críticas ou acréscimos.

A seguir, nas considerações finais, procuro voltar ao assunto presente na introdução e problematizar a separação disciplinar entre Retórica, Análise do Discurso e Sofística, dando ênfase a este último vocábulo. O objetivo seria apenas lançar a hipótese de que teríamos, no fundo, uma Arte Geral da Influência, que ora se concentra na formação prática e na preparação do indivíduo para o uso social da linguagem, ora na análise especulativa de discursos. Tais vertentes são complementares e, por isso, desenvolveram formulações teóricas comuns à $\mathrm{AD}$ moderna. 


\section{3. "Sofisticando" no final}

Algumas questões presentes na Sofística ${ }^{13}$ são essenciais para percebermos a ligação dessa arte com a Retórica e com os problemas centrais trabalhados pela AD. Gostaria então de aproveitar esse espaço para reportar algo dessa antiga e erroneamente desprezada arte da argumentação, no que tange principalmente o que chamamos, hoje, de condições de produção do discurso, o que se traduzirá num diálogo com as reflexões colocadas na parte introdutória. ${ }^{14}$

Embora com outras terminologias, os sofistas da Era de Péricles ressaltaram, cada um à sua maneira, a importância da subjetividade, do sujeito e das circunstâncias comunicativas para a instauração da adesão. Os seus fragmentos, os testemunhos e os trabalhos modernos que se ocupam do pensamento sofístico ${ }^{15}$ nos permitem dizer que um texto em si, com o seu conteúdo referencial, é capaz de produzir efeitos variados, seja em função de quem o concebe, de suas intenções, de suas expectativas, seja em função de quem o interpreta, com seus valores e representações. Como diria Górgias, o discurso produz seus efeitos (divinos, mágicos, farmacológicos) "misturando-se com a opinião da alma", daí a importância atribuída também naquela época ao que hoje chamamos instância de recepção do discurso. Dessa forma, não seria exagero dizer que o parâmetro "contexto comunicativo" era dado como essencial tanto para a produção, quanto para a compreensão dos discursos sociais.

A primeira coisa a se ressaltar no pensamento sofístico seria, valendo-me de terminologias modernas, a relatividade das significações via subjetividade nos ditos de Protágoras de Abdera. Este, segundo o testemunho de Diógenes Laércio, "(...) foi o primeiro a afirmar que sobre todos os assuntos existem dois argumentos [ou logoi] antitéticos (...)". (apud SOUSA; PINTO, 2005, p. 59) Dito de outra maneira, a todo argumento [ou logos/discurso] se contrapõe um outro argumento [ou outro logos/discurso]. (CLEMENTE DE ALEXANDRIA apud SOUSA; PINTO, 2005, p. 73) Esse pensamento revela duas características importantes do movimento sofístico: (i) a valorização do debate e do choque de pontos de vista, que fariam parte das questões públicas e políticas da Era de Péricles, e (ii) o pensamento crítico-relativístico, onde a verdade inexistia como algo a ser buscado e constatado, mas era dada como algo construído pelo discurso e pelo homem em razão de suas necessidades circunstanciais e sua atmosfera sociocultural (o Kairos, como veremos adiante). As reflexões filosóficosofísticas sobre a relatividade que nos cerca são centrais no sofista de Abdera. 
Seguindo o testemunho de Sexto Empírico, que cita um trecho de uma das obras perdidas (Verdade ou Discursos Demolidores),

(...) alguns incluíram também Protágoras de Abdera no grupo dos filósofos que aboliram o critério, porque afirma que todas as aparências e todas as opiniões são verdadeiras e que a verdade é algo de relativo, pois que tudo o que é aparência ou opinião para um indivíduo existe desde logo para ele. Assim, ao começar os Discursos Demolidores, declarou: "O homem é a medida de todas as coisas, das que são que são, das que não são que não são" (SEXTO EMPÍRICO apud SOUSA; PINTO, 2005, p. 78).

Diógenes Laércio (apud SOUSA; PINTO, 2005, p. 59), entre outros testemunhos, também ressalta essa mesma característica radical do pensamento relativístico de Protágoras, para o qual “(...) a alma nada mais é do que sensações, conforme afirma Platão no Teeteto, e que tudo é verdadeiro". Sendo assim, poderíamos dizer que, por trás do princípio filosófico do "homem medida", está a subjetividade enquanto componente experiencial, valorativo e avaliativo da "alma" humana. É por isso que uma mesma coisa pode parecer bela a um e o contrário a outro indivíduo, seguindo o comentário de Aristóteles sobre o pensamento de Protágoras (apud UNTERSTEINER, 1967, p. 41). ${ }^{16}$ Por sua vez, o testemunho de Sexto Empírico (apud SOUSA; PINTO, 2005, p. 70) salienta que essa variedade de critérios na avaliação das coisas está ligada ao fator idade e às disposições corporais, o que nos permite ver, enfim, nesse conjunto de fatores, a subjetividade em sua constituição social, afetiva e valorativa. Tratase de fatores cruciais, também, para as modalidades de recepção dos discursos e dos efeitos de sentido deles, uma vez que o auditório se deixa influenciar (ou não) em função de seus valores e representações. Vejamos outro ponto essencial do pensamento sofístico que o liga à $\mathrm{AD}$.

Protágoras e a Sofística em geral, com destaque para Górgias, deram também importância à noção de Kairos, termo traduzido geralmente como "circunstâncias oportunas" ou "ocasião propícia". Por trás dessa noção, acredito, encontra-se muito daquilo que hoje chamamos de condições de produção do discurso. O termo refere-se incialmente à competência técnica do orador em captar a "hora exata" para bem agir oratoriamente, o que se assemelha bem a conceitos modernos como competência discursiva e/ou situacional. Sendo 
assim, para os sofistas e todos aqueles que se ocupavam das artes do logos, adquirem importância “(...) a mobilização do oportuno, a atenção às particularidades de uma situação concreta, marcada pelas contingências do 'aqui' e do 'agora' (...)" (PINTO, 2000, p. 220). Dessa forma, o bom orador, em razão de sua experiência oratória e/ou do seu talento, é aquele que possui uma "presença de espírito" para agir discursivamente na hora certa e de modo pertinente.

Em muitos momentos, como nos mostra Mortara Garavelli (1995, p. 28-29), o termo Kairos pode ser entendido também como as próprias condições ou circunstâncias da comunicação, mesmo porque captar o momento oportuno para agir de modo pertinente/eficaz exige do orador uma capacidade de se adaptar à conjuntura particular na qual se desenvolve a comunicação, às suas restrições situacionais e também ao auditório visado. Em outros termos, a importância da noção teórica de kairos reside no fato de que “(...) a eficácia do dizer depende, acima de tudo, do sentido do que é apropriado ou conveniente num determinado momento, num contexto particular (...)" (PINTO, 2000, p. 225). Com base nessa mesma autora (Pinto), quando se busca sintetizar o pensamento de Górgias, podese dizer que o engano ou a sedução são instituídos pela força exterior de uma circunstância comunicativa, que define e fixa a dimensão retórica do discurso, revelando que "(...) logos e kairos conjugam-se no sentido de persuadir aquele que 'sofre' os seus efeitos" ${ }^{17}$ (PINTO, 2000, p. 225). Enfim, Pinto (2000, p. 226), citando Kennedy (1974, p. 66-67), salienta:

e uma vez que 'qualquer problema dado envolve escolha ou compromisso entre duas antíteses', apenas a consideração do kairos, isto é, do tempo, lugar e circunstância (...) pode resolver o dilema e conduzir à escolha da verdade relativa à acção'. No âmbito da retórica, o conceito de kairos abrange a organização dos diversos elementos do discurso de forma a que o mesmo se adapte 'à variedade multiforme da vida', bem como à maneira de ser daquele que fala e daquele que ouve.

Em outras palavras, temos aqui claras menções ao que, na linguística discursiva, chamamos de a força desambiguizadora do contexto no processo de compreensão dos atos de linguagem. Ao mesmo tempo, nota-se a ligação (e a dependência) dos processos de estruturação dos enunciados com as 
necessidades daqueles que comunicam numa dada conjuntura. Sendo assim, as discussões sofísticas sobre o Kairos englobam muitos elementos de interesse da AD moderna, pois temos aqui, embora com outras terminologias, uma preocupação central com as ditas condições de produção do discurso e uma teorização acerca do sujeito e da subjetividade, conforme foi visto há pouco no pensamento de Protágoras.

Volto, então, às indagações da parte introdutória, que problematizam a separação da Retórica, da Sofística e da Análise do Discurso como "mundos" diversos no que concerne aos estudos sobre a argumentação, deixando como interrogação se não teríamos, no fundo, uma arte maior dos estudos sobre a influência capaz de se recompor no interior da AD. Tal arte, ao longo da história, ora se ramificou numa dimensão performativa, voltando-se para o desempenho prático dos oradores, ora se ramificou em estudos especulativos sobre o que seria capaz de persuadir em termos de efeitos possíveis. Acredito que todas as vertentes teceram e tecem considerações teóricas úteis ao trabalho de analisar discursos e, ao mesmo tempo, não deixaram de lado considerações de cunho linguístico e gramatical. Tal assunto se mostra de imensa complexidade e mereceria certamente um trabalho à parte, seguido de acirradas discussões.

Procurei, enfim, apenas chamar a atenção para o problema do esquecimento da Sofística por parte da AD e para a impossibilidade de separarmos a AD dos estudos antigos sobre a influência, considerando-a um campo de "questões novas". Apenas a título de ilustração e curiosidade, deixo aos leitores trechos de uma obra sofística anônima, os Dissoi Logoi (Duplos Discursos ou Discursos Contraditórios). A té hoje não se conhece o autor, nem mesmo se se tratava de um texto de especulação teórica ou mesmo um caderno (ou modelo) de exercícios para os alunos desenvolverem a habilidade oratória via argumentação pelos contrários. Vejamos os trechos (SOUSA e PINTO, 2005, p. 283 e seguintes):

[Dissoi Logoi - Duplos Discursos ou Discursos Contraditórios]

"1. Do bem e do mal

(1) Duplos discursos sobre o bem e o mal são proferidos na Grécia por aqueles que se dedicam à filosofia. Uns dizem que uma coisa é o bem e outra coisa é o mal; mas outros dizem que são o mesmo, e que uma coisa é um bem para uns, enquanto para outros é um mal ou que, para a mesma pessoa, uma coisa é um bem numa certa ocasião e um mal noutra ocasião. (2) Eu próprio partilho da perspectiva destes 
últimos e analisarei o argumento a partir da vida humana, cujos cuidados são a comida, a bebida e os prazeres sexuais; tudo isto é um mal para o que está doente, mas é um bem para o que está de saúde e deles sente necessidade. (3) E o desregramento nestas coisas é um mal para os desregrados, mas é um bem para o que negocia e vende. E a doença é um mal para os que estão doentes, mas é um bem para os médicos. E a morte é um mal para os que morrem, mas é um bem para os comerciantes de serviços funerários e para os fornecedores de túmulos (...)

3. Do justo e do injusto

(1) Também se proferem duplos discursos sobre o justo e o injusto. Uns defendem que uma coisa é o justo e outra coisa o injusto; outros dizem que justo e injusto são o mesmo. Quanto a mim, tentarei defender este útimo argumento. (2) E, em primeiro lugar, direi que é justo dizer mentiras e enganar. Dir-se-ia que fazer isto aos inimigos é [decente e justo] e é vergonhoso e perverso faze-lo [aos amigos]. [Mas como é que é justo faze-lo aos inimigos] e não aos mais amados? Por exemplo, aos pais: se o pai ou a mãe precisarem beber ou ingerir um medicamento e não quiserem, não é justo dar-lho na comida ou na bebida e não dizermos que se encontra aí? (3) Por conseguinte, é justo mentir e enganar os pais. E é justo roubar o que pertence aos amigos e exercer violência sobre os mais amados. (4) Por exemplo, se um dos familiares, abatido e transtornado por qualquer motivo, estiver prestes a matar-se com um punhal ou com uma corda ou com qualquer outro instrumento, é justo roubar-lhe esses utensílios, se possível, ou se se chegar demasiado tarde e já tiver o instrumento na mão, não é justo arrancar-lho à força? (...)"

Nessa obra enigmática, enfim, o anônimo autor deixa de modo interessante claro a relatividade da verdade, a importância do kairos e da subjetividade humana na interpretação/definição das palavras, das coisas e dos conteúdos. Ao falar do bem e do mal, do justo e do injusto (e de outros parâmetros presentes na obra completa), tenta-se provar que tudo é uma coisa ou outra apenas em função das circunstâncias e do tempo oportuno/preciso. Sendo assim, não existe uma verdade em si ou apenas uma interpretação possível para os logoi sociais: tudo depende das ocasiões propícias e dos interesses e valores dos sujeitos sociais que se valem da linguagem. 


\section{Notas}

${ }^{1}$ Essa "quebra" refere-se ao desmembramento dos estudos sobre a influência, onde se teria, de um lado, a Retórica transformada em mera arte dos estudos das figuras de linguagem, desprovida de sua dimensão controversa e persuasiva. De outro lado, ter-se-ia a Dialética em sua acepção lógica, no campo das discussões especializadas éticas e filósoficas e, por fim, pode-se mencionar a Sofística em seu sentido negativo usual, entendida como a arte de manipular através de sofismas. Aqui não se adota separações do gênero.

${ }^{2}$ Sobre a abordagem das emoções na AD, pode-se citar, como exemplo, Machado, Menezes e Mendes (2007), Plantin, Doury e Traverso (2000) e tantos outros trabalhos elencados no interior dessas referências.

${ }^{3}$ Sobre a interrelação das provas retóricas na instauração da adesão, cada vez mais não vistas como elementos independentes, ver Galinari (2007b) e Menezes (2007).

${ }^{4}$ Dois exemplos de como a dimensão genérica do discurso foi descrita em proveito da análise podem ser vistos nos trabalhos de Lessa (2009), que descreveu o gênero ensaio, e Galinari (2007a), que descreveu o gênero hino.

${ }^{5}$ (...) a análise argumentativa se apresenta como um setor da análise do discurso (AD), na medida em que ela procura elucidar funcionamentos discursivos explorando uma palavra situada e ao menos parcialmente determinada. Como a definem as tendências francesas contemporâneas (...), trata-se de uma disciplina (1) que associa a palavra a um lugar social e a quadros institucionais, (2) que ultrapassa a oposição texto/contexto: o estatuto do orador, as circunstâncias sócio-históricas nas quais ele toma a palavra ou a caneta, a natureza do auditório visado, a distribuição prévia dos papéis que a interação aceita ou tenta impedir, as opiniões ou as crenças que circulam na época, são os vários fatores que constroem o discurso e que a análise interna deve levar em conta, (3) que recusa de colocar na origem do discurso "um sujeito individual e autosuficiente" (MAZIÈRE, 2005, p. 5): o locutor é sempre, como o auditório, atravessado pela palavra do outro, pelas ideias recebidas e as evidências de uma época, e por isso ele é condicionado pelas possibilidades de seu tempo. (Tradução minha)

${ }^{6}$ Em Galinari (2007c), procurei adaptar esse quadro a um corpus formado por hinos de Villa-Lobos no contexto político da Era Vargas.

${ }^{7}$ Se é verdade, como dizia Bakhtin, que "em nenhum caso a situação extraverbal não é a única causa exterior do enunciado, [que] ela não age de fora como uma força mecânica", mas entra no enunciado como "um constituinte necessário de sua estrutura semântica", então é necessário reconhecer que no seu uso corrente a noção de "condições de produção" se revela de fato insuficiente. 
8 “A enganosa evidência da concepção que opõe a um 'interior' do texto o 'exterior' das condições que o tornam possíveis".

${ }^{9}$ Aliás, por isso, prefiro evitar termos como "extralinguístico", "extraverbal”, "prédiscursivo" e similares.

${ }^{10}$ Maingueneau (1991) aborda com mais detalhes o conceito de interdiscurso e, principalmente, o define mais precisamente, no sentido de torná-lo um conceito mais operativo para a $\mathrm{AD}$, revelando-o de três maneiras possíveis: (i) como universo discursivo, (ii) como campo discursivo e (iii) como espaço discursivo. Como aqui não temos espaço para entrar em detalhes, remetemos o leitor à mencionada obra.

${ }^{11}$ Para maiores detalhes acerca dos elementos dóxicos, é interessante a seguinte bibliografia: sobre a doxa em geral e no campo da argumentação, ver Amossy (2006); especificamente sobre os valores, ver Perelman e Olbrechts-Tyteca (2002); sobre estereótipos, cliches e outros, ver Amossy (1991) e Amossy et Pierrot (1997).

${ }^{12}$ Note-se, portanto, que o termo objeto discursivo é aqui entendido de maneira bem abrangente.

${ }^{13}$ Ao falar da Sofística e seus personagens, refiro-me a Protágoras de Abdera, Górgias de Leontini, Pródico de Ceos, Trasímaco da Calcedônia, Hípias de Elis, Crítias, Antifonte e outros pensadores em atividade a partir do século V a. C., quando Péricles instituiu a democracia ateniense. Não se deve confundi-los com as atividades de Córax e Tísias na Sicília grega.

${ }^{14}$ São vários os trabalhos e estudos contemporâneos que resgatam o valor filosófico e educativo dos sofistas, livrando-os do preconceito platônico-aristotélico que os consagrou como enganadores, mercenários ou sujeitos que do conhecimento detinham apenas a aparência. Como exemplo, podemos citar: Untersteiner (2008), Vignali (2007), Pinto (2000), Romilly (1988) e Saitta (1938), entre outros.

${ }^{15}$ Como se sabe, o conhecimento produzido pelos sofistas desapareceu quase que totalmente. O que nos resta são apenas alguns fragmentos e, principalmente, testemunhos como os de Diógenes Laércio, Sexto Empírico, Platão, Aristóteles e tantos outros que citam e discutem as questões colocadas pelos sofistas. Felizmente, hoje contamos com autores que reuniram em uma só obra tais fragmentos e testemunhos antigos por meio do grego e do latim. Os primeiros foram Diels e Kranz que os traduziram para o alemão, na obra Die Fragmente der Vorsokratiker. Algum tempo depois, o italiano Untersteiner (1967) traduziu-os para seu idioma, porém com uma edição mais completa e aperfeiçoada (I Sofisti: testimonianze e framenti). Sousa e Pinto (2005), por sua vez, realizaram uma versão em português a partir dos trabalhos anteriores, a qual estamos utilizando neste artigo por questões de comodidade. 
${ }^{16}$ A relatividade das verdades e das significações das palavras e das coisas mostrase também no testemunho de Platão (Crátilo): Protágoras sustentava que “(...) o homem é a medida de todas as coisas, tal como as coisas me parecem ser, assim elas são para mim; tal como elas te parecem a ti, assim elas são para ti” (PLATÃO apud SOUSA e PINTO, 2005, p. 70).

${ }^{17}$ Unterstainer (2008, p. 169), que em sua obra analisa em detalhes tais questões, ressalta, reproduzindo o pensamento sofístico, que "il rilievo impresso a um logos o a quello opposto è opera di Kairos e l'effetto è, appunto, apate". ["o relevo impresso a um logos ou àquele oposto é obra do Kairos e o efeito é, certamente, apate (engano/ilusão)"']

\section{Referências bibliográficas}

AMOSSY, Ruth. L'argumentation dans le discours. Deuxième édition. Paris: Armand Colin, 2006.

AMOSSY, Ruth. Les Idées Reçues. Sémiologie du Stéréotype. Paris: Nathan, 1991. AMOSSY, Ruth; PIERROT, Anne Herschberg. Stéréotypes et Clichés : langue, discours, société. Paris: Nathan, 1997.

ANSCOMBRE, Jean-Claude; DUCROT, Oswald. L'argumentation dans la langue. Bruxelles: Mardaga, 1983.

CHARAUDEAU, Patrick. Le contrat de communication de l'information médiatique. In: Le Français dans le Monde. Paris: Hachette/Edicef, Juillet 1994, numéro spécial, p. 8-19.

CHARAUDEAU, Patrick. Grammaire du Sens et de l'Expression. Paris: Hachette, 1992. CHARAUDEAU, Patrick. Langage et Discours. Paris: Hachette, 1983

GALINARI, Melliandro Mendes. A Era Vargas no Pentagrama: dimensões políticodiscursivas do canto orfeônico de Villa-Lobos. 2007a. Tese (Doutorado em Linguística) - Faculdade de Letras, UFMG, Belo Horizonte.

GALINARI, Melliandro Mendes. As Emoções no Processo Argumentativo. In: MACHADO, I. L.; MENEZES, W.; MENDES, E. As emoções no discurso. Rio de Janeiro: Lucerna, 2007b. p. 221-239.

GALINARI, Melliandro Mendes. Os Hinos Cívicos de Villa-Lobos e a Era Vargas: uma abordagem modular em Análise do Discurso. In: MARINHO, J. H. C.; PIRES, M. S. de O.; VILLELA, A. M. N. Análise do Discurso: ensaios sobre a complexidade discursiva. Belo Horizonte: CEFET, 2007c. p. 67-86. 
LESSA, Cláudio Humberto. Marcação e Destituição de Identidade PolíticoDiscursiva em Ensaios de Intelectuais de Esquerda: Valores, Imaginários e a Projeção de Auto e Hetero-Imagens. 2009. Tese (Doutorado em Linguística) Faculdade de Letras, UFMG, Belo Horizonte.

MACHADO, Ida Lucia; MENEZES, William; MENDES, Emília. As Emoções no Discurso. Rio de Janeiro: Lucerna, 2007.

MACHADO, Ida Lucia. Uma Teoria de Análise do Discurso: A Semiolinguística. In: MARI, Hugo; MACHADO, Ida Lucia; MELLO, Renato de. Análise do Discurso: Fundamentos e Práticas. Belo Horizonte: NAD/FALE/UFMG, 2001. p. 39-62.

MAINGUENEAU, Dominique. L'Analyse du Discours: introduction aux lectures de l'archive. Paris: Hachette, 1991.

MARINHO, Janice Helena Chaves; PIRES, Maria Sueli de Oliveira; VILLELA, Ana Maria Nápoles. Análise do Discurso: ensaios sobre a complexidade discursiva. Belo Horizonte: CEFET, 2007.

MENEZES, William Augusto. Um Pouco sobre as Emoções no Discurso Político. In: MACHADO, Ida Lucia; MENEZES, William; MENDES, Emília. As Emoções no Discurso. Rio de Janeiro: Lucerna, 2007. p. 310-328.

MORTARA GARAVELLI, Bice. Ricognizioni. Retorica, grammatica, analisi di testi, Napoli, Morano, 1995.

PÊCHEUX, Michel. Análise automática do discurso (AAD-69). In: GADET, F. e HAK, T. Por uma Análise Automática do Discurso: uma introdução à obra de Michel Pêcheux. Campinas: Unicamp, 1997. p. 61-161.

PERELMAN, Chaïm; OLBRECHTS-TYTECA, Lucie. Tratado da Argumentação: a Nova Retórica. São Paulo: Martins Fontes, 2002.

PINTO, Maria José Vaz. A Doutrina do Logos na Sofística, Lisboa, Edições Colibri/ Instituto de Filosofia da Linguagem, 2000.

PLANTIN, Christian; DOURY, Marianne; TRAVERSO, Véronique. Les Émotions dans les interactions. Lyon: Presses universitaires de Lyon, 2000.

PLANTIN, Christian. L'argumentation. Paris: Seuil, 1996.

ROMILLY, Jacqueline de. Les Grands Sophistes dans l'Athènes de Périclès. Paris : Éditions de Fallois, 1988.

ROULET, Eddy; FILLIETTAZ, L.; GROBET, A. Un modèle et un instrument d'analyse de l'organisation du discours. Bern: Lang, 2001. 
ROULET, Eddy ; PIRES, Sueli. Uma Visão Modular da Complexidade Discursiva. In: MARI, Hugo; MACHADO, Ida Lucia; MELLO, Renato de. Análise do Discurso: Fundamentos e Práticas. Belo Horizonte: NAD/FALE/UFMG, 2001. p. 63-91.

SAITTA, Giuseppe. L'Illuminismo della Sofistica Greca. Milano: Fratelli Bocca, 1938.

SOUSA, Ana Alexandre Alves de; PINTO, Maria José Vaz. Sofistas: Testemunhos e Fragmentos. Lisboa: Imprensa Nacional - Casa da Moeda, 2005.

TOULMIM, Stephen. E. The uses of argument. Cambridge: Cambridge University Press, 1958.

UNTERSTEINER, Mário. I Sofisti. Milano: Bruno Mondadori, 2008.

UNTERSTAINER, Mario. Sofisti: Testimonianze e Frammenti, Firenze, La Nuova Italia, 1967.

VIGNALI, Daniele. I Sofisti: Retori, Filosofi ed Educatori. Roma: Armando Editore, 2007. 